Revista Eletrônica do Mestrado em Educação Ambiental

\title{
Aprisionando espíritos e fazendo imagens: por uma cosmopolítica das imagens
}

\section{Kaiowá}

Iulik Lomba de Farias ${ }^{1}$

Universidade Federal da Grande Dourados ORCID https://orcid.org/0000-0002-4827-8736

\author{
Leif Grünewald ${ }^{2}$ \\ Universidade Federal da Grande Dourados \\ ORCID https://orcid.org/0000-0001-7399-389X
}

\begin{abstract}
Resumo: O artigo, ora apresentado, tem por objetivo desenvolver reflexões entorno da relação que cineastas Kaiowá do Cone Sul de Mato Grosso do Sul estabelecem com as imagens (ta `anga), suas conexões com a cosmologia e regimes de xamanismo. A partir da identificação de agentes cosmopolíticos imbricados nas redes de relacionalidade manejadas por intermédio das imagens, teceremos mosaicos relacionais mobilizados entre as ta'anga e os sujeitos humanos e não-humanos, para vislumbrarmos a noção de imagem sustentada pelo pensamento Kaiowá. Em nossa hipótese, o exercício contínuo de conceituação do que viria a ser uma imagem, por parte dos cineastas em questão, pode ser elucidado por agenciamentos cosmopolíticos que balizam ontologicamente os filmes realizados por eles e que propõem interconexões entre realidades simultâneas, evidenciando, assim, a complexidade agentiva das imagens no multiverso Kaiowá.
\end{abstract}

Palavras-chave: Cosmopolítica; Imagens; Cosmologia Kaiowá

\section{Capturar espíritus y crear imágenes: para una cosmopolitica de las imágenes Kaiowá}

Resumen: El artículo presentado aquí tiene como objetivo desarrollar reflexiones sobre la relación que los cineastas Kaiowá del Cono Sur de Mato Grosso do Sul establecen con las imágenes (ta anga), sus conexiones con los regímenes de cosmología y chamanismo. Basados en la identificación de agentes cosmopoliticos entrelazados en las redes de relacionalidad manejadas a través de imágenes, tejeremos mosaicos relacionales entre las ta'anga, sujetos humanos y no humanos, para vislumbrar la noción de imagen apoyada por el pensamiento Kaiowá. En nuestra hipótesis, el ejercicio de conceptualización de lo que se convertiría en imagen por parte de los cineastas en cuestión, puede ser dilucidado por agencias cosmopoliticas que guían ontológicamente

\footnotetext{
${ }^{1}$ Bacharel em Cinema e Audiovisual pela Universidade Federal Fluminense (UFF) e Mestre em Antropologia Social pela Universidade Federal da Grande Dourados (UFGD). e-mail: iulikfarias@ yahoo.com.br

${ }^{2}$ Graduado em Ciências Sociais pela Universidade Federal do Espírito Santo (UFES), Mestre e Doutor em Antropologia Social pela Universidade Federal Fluminense (UFF). e-mail: leifgrunewald@ gmail.com

Rev. Eletrônica Mestr. Educ. Ambient. Rio Grande, Dossiê temático "Imagens: resistências e criações cotidianas", p. 08-27, jun. 2020. E-ISSN 1517-1256
} 
las películas realizadas por ellos, y proponen interconexiones entre realidades simultáneas, que muestran la complejidad de las imágenes en el multiverso Kaiowá.

Palabras clave: Cosmopolitica; Imágenes; Cosmología Kaiowá

\section{Capturing spirits and making images: for a cosmopolitics of Kaiowá images}

Abstract: The article presented here aims to develop reflections around the relationship that Kaiowá filmmakers from the Southern Cone of Mato Grosso do Sul, establish with the images (ta anga), their connections with cosmology and shamanism regimes. Based on the identification of cosmopolitical agents intertwined in the networks managed through images, we will weave relational mosaics mobilized between ta'anga, human and non-human subjects, in order to better glimpse the notion of image supported by Kaiowá thought. In our hypothesis, the continuous exercise of conceptualization of what would become an image on the part of the filmmakers in question, can be elucidated by cosmopolitical agencies that ontologically guide the films made by them, and propose interconnections between simultaneous realities, which show the complexity agence of images in the Kaiowá multiverse.

Keywords: Cosmopolitics; Images; Kaiowá Cosmology

Alguma introdução

O presente artigo vislumbra prolongar reflexões desenvolvidas na dissertação de mestrado, Ta'anga Ymã: Perspectivismo, Cosmopolítica, E Imagens Kaiowá E Mbya -O Convívio Entre A Visualidade E A Não-Visualidade, defendida no PPGANT/UFGD (Programa de Pós Graduação em Antropologia/UFGD), sob orientação do Prof ${ }^{\circ}$ Dr. Leif Grünewald, coautor deste texto.

Tomando como base o que discutimos ao longo do texto da dissertação, nossa aposta é a de que os agenciamentos cosmopolíticos, mobilizados nas redes de relacionalidade às quais as imagens estão imbricadas nos regimes de conhecimento Kaiowá, podem sinalizar, a nosso ver, uma espécie de desestabilização de acepções semióticas, que tendem a conceituar a imagem e a leitura de filmes por meio de sistemas de representação e discurso miméticos.

Conforme discutimos naquela ocasião, diferentes agentes cosmológicos concernentes aos circuitos relacionais habitados por imagens no pensamento Kaiowá promovem complexas interferências entre a imagem e variadas categorias de alteridades humanas e não-humanas, visíveis e não-visíveis, que extrapolam uma concepção representacional e meramente discursiva das obras cinematográficas produzidas pelos cineastas desse povo; e serão exatamente essas conexões agentivas que nos interessarão enquanto "objeto" para a análise aqui empenhada.

Três aspectos característicos de tais conexões, identificados ao longo do mestrado, serão revisitados e aprofundados agora. O primeiro deles diz respeito a uma espécie de convívio e ambivalência de caracteres visíveis e invisíveis nas imagens Kaiowá; o segundo 
corresponde à recorrência de procedimentos de transcorporalidade derivados do xamanismo, aos quais as imagens também estariam vinculadas, produzindo diferenciações conceituais do que viria a ser uma imagem nos mosaicos relacionais dos Kaiowá com seus outros não-humanos; e o terceiro reside em um mapeamento de acepções cosmológicas em torno de uma possível perspectiva exercida pela câmera, à luz da teoria etnográfica do perspectivismo ameríndio (VIVEIROS DE CASTRO, 1996; LIMA, 1996), que delimitaria um modo de existência específico e uma determinada autonomia corpórea extrahumana do dispositivo-câmera.

Alguns elementos analisados durante a produção da dissertação nos forneceram um recorte do ponto de vista de nossos interlocutores cineastas Kaiowá, acerca das capacidades agentivas das ta'anga (imagens), que foram apresentadas, fundamentalmente, como espécies de "espíritos aprisionados, enjaulados", direcionando a investigação etnográfica para um esforço de identificação das redes de relação cosmopolíticas entre as imagens e os outros seres e categorias não-humanos, contemplados via alguma descrição etnográfica da sociocosmologia Kaiowá.

Durante as pesquisas de campo, em interlocução com Eliel Benites e Ademilson Concianza (Kiki), cineastas Kaiowá das aldeias Tey Kue e Panambizinho, situadas no Mato Grosso do Sul, nos municípios de Caarapó e Dourados, respectivamente; tal constatação da (re)conversão dos espíritos em imagem conectava-se, em inúmeras ocasiões, a uma série de procedimentos e práticas transcorpóreas concernentes também ao xamanismo.

Conforme as incursões etnográficas de desenvolviam, as dimensões cosmopolíticas das ta'anga se apresentavam por meio de agenciamentos sofisticados, que afetavam circuitos humanos e não-humanos simultâneos via transcorporalidade; e as imagens, ela próprias, passavam também a circunscrever uma categoria de alteridade mais-que-humana, atravessada por seres e sujeitos exógenos e endógenos a um determinado filme, produtores de atualizações cosmológicas dentro e fora de uma mesma imagem.

\section{Cosmopolítica e imagens de dupla-face}

O termo utilizado pelos Kaiowá para nomear as imagens, ta'anga, pode ser aplicado para uma ampla variedade de corpos imagéticos: desenhos, mapas, fotografias e, é claro, as imagens cinematográficas. As agências múltiplas com as quais essas imagens afetam categorias humanas e não-humanas, (re)posicionam a noção Kaiowá de imagem em 
um mosaico relacional extremamente complexo e superpovoado de seres, substâncias e objetos; os quais sofrem inferências das imagens, e exercem também afetações sobre elas.

Tais possibilidades de mútua interferência "política" dos não-humanos sobre as imagens e das imagens sobre eles, reincidem nas acepções de Bruno Latour (2007, p. 454) referentes à noção de cosmopolítica:

[...] The presence of cosmos in cosmopolitics resists the tendency of politics to mean the give-and-take in an exclusive human club. The presence of politics in cosmopolitics resists the tendency of cosmos to mean a finite list of entities that must be taken into account. Cosmos protects against the premature closure of politics, and politics against the premature closure of cosmos. [...] cosmos is to mean anything, it must embrace, literally, everything-including all the vast numbers of nonhuman entities making humans acts. [...] (LATOUR, 2007, p. 454)

Pudemos perceber, por assim dizer, que filmar um mbaraka, chocalho ritual Kaiowá, não se tratava, por conseguinte, de apenas reproduzir imageticamente a existência do "chocalho" entre os humanos; mas, acima de tudo, conjecturava interferir na relacionalidade cosmopolítica agenciada por ele em uma multiplicidade de relações com outros sujeitos e agentes mais-que-humanos, como os angüere (espíritos maléficos), os angüe (espíritos benéficos e/ou reflexos), os nhanderu e nhandesy (xamãs), os jara (donoscosmológicos) do mbaraka, os xamãs mortos que o utilizaram no passado, e assim por diante.

Esse jogo de papéis agrupados e interconectados, que se tece entre os sujeitos mbaraka, xamãs, jara, nhanderu, nhandesy, angüere, angüe, entre outros- por não serem fixos, intransponíveis e inalienáveis, nos fornece uma imagem instigante da noção de cosmopolítica formulada por Isabelle Stengers (2018), que entende a "proposição cosmopolítica" como a possibilidade de presentificação da "insistência" de um "pensamento coletivo", a partir do agenciamento atualizável de seres e coisas, que evidencia uma espécie de construção política desse pensamento através da operacionalidade de um "duplo cósmico".

Para a autora, agenciar cosmopoliticamente um conjunto de agentes humanos e não-humanos possibilitaria que "o pensamento coletivo se construa 'em presença' da questão insistente que eles fazem existir" (STENGERS, 2018, p. 448). Em outras palavras, a "proposição cosmopolítica" de Stengers traz à baila "questões" políticas que humanos e não-humanos fazem existir em um campo de experiência compartilhado por eles; e que a política "crua" dos humanos não abarca, e tampouco a ideia de cosmos "uno" dá conta.

Rev. Eletrônica Mestr. Educ. Ambient. Rio Grande, Dossiê temático "Imagens: resistências e criações cotidianas", p. 08-27, jun. 2020. E-ISSN 1517-1256 
O "duplo cósmico", porquanto, opera alargando a ação política humana para além do socius e, ao mesmo tempo, esgarça a ação política não-humana para além do cosmos. Em nosso caso, entre os Kaiowá, os mosaicos relacionais, aos quais estão imbricadas as imagens, sofrem atualizações múltiplas e contínuas nos papéis assumidos por cada um dos agentes envolvidos nesse jogo; ao passo que o dispositivo-cinema, progressivamente, recruta novos agentes para essas relações.

As imagens que anteriormente eram manejadas e postas em diálogo com/por xamãs e espíritos, por exemplo, agora são produzidas, evocadas, multiplicadas e disseminadas por intermédio de câmeras, computadores, projetores, televisores, celulares, óculos de realidade virtual e etc. Variados corpos mecânicos reivindicam suas agências sobre as imagens e, consequentemente, sobre as redes de relação mobilizadas por essas imagens, emoldurando o quadro cosmopolítico atualizável descrito por Stengers (2018) e que, aos olhos da autora, nos traria à tona o papel da imagem no "pensamento coletivo" Kaiowá.

Pois bem, dito isso, voltemos a algumas impressões/constatações que obtivemos ao longo da etnografia produzida para a escrita da dissertação. Nossos interlocutores cineastas nos reportaram inúmeras vezes que o ato de produzir/construir uma imagem nesse contexto cosmopolítico relacional promoveria uma espécie de aprisionamento de potências nãovisíveis conectadas aos corpos de coisas e seres como o mbaraka, por exemplo, que transformaria imagem e o mbaraka em um corpo-outro; em uma espécie de imagemcorpo-mbaraka, preenchida de intencionalidades e capacidades agentivas, as quais alargariam exponencialmente a ideia anglo-europeia de imagem; exatamente por articular caracteres indiciais de uma espécie de autonomia corpórea e subjetiva desse ser-imagem.

Em outras palavras, as ta'anga, ao figurarem como imagens possuidoras de autodeterminação ontológica, romperiam com sua redução a simples representações ou a ficções e realidades imaginárias de valores e projeções subjetivas sobre uma natureza unitária, dando vistas a uma espécie de "pragmática especulativa" (DEBEAISE; STENGERS, 2016) expressa em questões, por exemplo, do efeito que produzem ao atuarem em circuitos de relações humanas e não-humanas simultâneas, que extrapolam a significação, exasperam a representação, e produzem efeitos visíveis e não-visíveis, nos mais variados domínios de experiência sociocosmológica.

Quando nos referimos a esse tipo de multiplicação das significações, não queremos dizer com tal referência que as imagens ou as sequências de imagens, acabem por não 
significar nada no multiverso ${ }^{3}$ (VIVEIROS DE CASTRO, 2012) de nossos interlocutores, muito pelo contrário, pois ao agenciarem uma multiplicidade de significações, as ta'anga estão a significar além da significação; ou melhor, as imagens produzidas via perspectivas indígenas, possibilitam tanto o alargamento da significação, quanto da representação, exatamente por corporificarem em sua materialidade, caracteres imagéticos, ao passo que também corporificam em si mesmas, caracteres incompatíveis com a imagetização.

Dito de outra forma, as ta`anga possuem, em si mesmas, corpos invisíveis formadores de sua materialidade; que caracterizam a relação com as imagens como uma experiência dupla, na qual inúmeros corpos invisíveis, sobrescritos sobre as imagens, estão igualmente imbricados. Trocando em miúdos, as ta`anga são compostas, também, por corpos não-visíveis nas imagens físicas, porém inegavelmente componentes da fisicalidade de tais imagens.

Em diálogo com Stengers (2011) e Latour (2007), Viveiros de Castro (2012) corrobora do entendimento de que a cosmopolítica ameríndia seria uma espécie de "ontologia política do sensível" que, antes de dar a ver a presentificação do "pensamento indígena", seria ela própria, a cosmopolítica, a imagem do que os índios chamam pensamento; que, segundo ele, seria "algo que se passa pela cabeça, não nasce e nem fica lá"; mas, pelo contrário, se "exprime como afeto incorporante", "antropofagia política" e "transformação do e no outro", exatamente pelo aspecto de que a cosmopolítica "atualiza um outro universo que o nosso, ou outra coisa que um uni-verso" (VIVEIROS DE CASTRO, 2012, p.157-158).

Nesse sentido, ao nosso ver, faz-se plausível pensarmos uma "cosmopolítica das imagens Kaiowá", exatamente em função das ta'anga, serem modos de existência corpóreos, capazes de transformar-se em outros modos de existência também corpóreos, para, assim, se relacionarem corporalmente com humanos e com não-humanos nesse multiverso. Dito de outra forma, as afecções múltiplas e atualizáveis, visíveis e nãovisíveis das imagens, por estarem ativas e agentes em circuitos transgressores das atribuições imagéticas e oculares dos regimes de significação visuais, sinalizam a

\footnotetext{
${ }^{3}$ Convém notar que a noção de "multiverso" foi cunhada originalmente por William James, contraposta a noção de "universo". Enquanto esta faria referência a uma unidade previamente concebida (o que justificaria um conjunto de operações de unificação e unitarização), aquela remeteria a um conjunto de partes desconectadas. Conforme Isabelle Stengers (2011) observou acerca da noção de multiverso, a não-existência real de um universo não significaria que o 'multiverso' seria a palavra final. Para James, segundo Stengers, esta faria referência a um mundo "em continua elaboração" [in the making] na forma de um 'pluriverso', no qual a pluralidade comunica divergências.
}

Rev. Eletrônica Mestr. Educ. Ambient. Rio Grande, Dossiê temático "Imagens: resistências e criações cotidianas", p. 08-27, jun. 2020. E-ISSN 1517-1256 
capacidade agentiva das ta`anga em domínios invisíveis e conjecturam suas formas de agência como afeto incorporante e antropofágico, por exemplo.

Esta outra imagem do que seria uma imagem, portanto, não se relacionaria unicamente com o "invisível" posicionado nos espaços além das fronteiras e limitações do enquadramento, como uma espécie de não-visto "fora de quadro" ou "fora de campo"; pois, as formas agentivas "invisíveis" seriam, para empregas à glosa Kaiowá, "aprisionadas", “enjauladas" e, por conseguinte, sobreescritas nas imagens, mesmo que ocularmente permaneçam invisíveis.

Vejamos um caso hipotético: ao se filmar as margens de um rio onde os Kaiowá afirmam estarem dormindo sereias sobre as pedras, não é porque não vemos sereias imagetizadas nas imagens, que elas não estão efetivamente presentes nessas imagens. Muito além do que habita o "fora de quadro" ou o "fora de campo", os caracteres invisíveis são corpos não-visuais inscritos no corpo da imagem, como se compusessem um tipo de fundo virtual de realidade.

Este fundo virtual conjecturaria, a nosso ver, uma espécie de plano de transformabilidade dos corpos, ativo ininterruptamente, para que a atualização corporal das imagens aconteça. Em outras palavras, registrar cinematograficamente o interior de uma floresta não se trata apenas de registrar suas árvores, folhas, pedras, pássaros e macacos; é, antes de tudo, promover o 'encarceramento', no corpo das imagens, das potências virtuais invisíveis oriundas dos jara (espíritos-guardiões), das mboi-jaguá (cobras-com-cabeça-decachorro), dos moape (tamanduás gigantes comedores de gente) etc.

Essa convivência entre o visível e o "invisível”, nas imagens de filmes indígenas, tem sido progressivamente complexificada por pesquisadores que se debruçam sobre o cinema realizado por povos ameríndios. André Brasil e Bernard Belisário (2016), orientados pela acepção de que as capacidades da câmera operariam relações de afetações mútuas entre o que se vê, e o que não se vê na realidade filmada; sinalizam uma espécie de alargamento fenomenológico da categoria imagem:

[...] tudo aquilo que se inscreve concretamente na imagem, em sua gênese "indicial" - entra em relação com uma outra dimensão, digamos, cosmológica - constituída por processos muitas vezes invisíveis que afetam a imagem, mas que a ultrapassam. Assim como em situações de xamanismo e ritual o corpo é afetado por agências cuja presença não nos é dado ver, também a câmera o será: o que ela apreende e inscreve será efeito da relação não apenas com os objetos e fenômenos visíveis, mas também com essas agências invisíveis [...] (BRASIL; BELISÁRIO, 2016, p. 604).

Rev. Eletrônica Mestr. Educ. Ambient. Rio Grande, Dossiê temático "Imagens: resistências e criações cotidianas", p. 08-27, jun. 2020. E-ISSN 1517-1256 
Assim como identificamos nas incursões etnográficas entre os Kaiowá, André Brasil e Bernard Belisário, no trecho acima citado, salientam interconexões entre a produção de imagens fílmicas e aquilo a que se referem sob o termo de "situações de xamanismo", entendendo-as como fenômenos pragmaticamente experienciados, por meio de uma "dobra ontológica" visível-invisível.

Nesse sentido, compartilhamos do entendimento de que, antes de temas e/ou performances rituais filmadas, tais "situações de xamanismo" agenciam uma interpenetração entre mundos imagéticos e não-imagéticos, visuais e não-visuais, na própria materialidade corpórea das imagens produzidas por intermédio da câmera.

Desse modo, o "que se inscreve concretamente na imagem" seriam dimensões bifaciais, que assegurariam às imagens compilações de caracteres visualizáveis e nãovisualizáveis em si mesmas; transformando essas imagens, também, em corpos bifacializados nos quais o invisível encontra-se igualmente inscrito sobre o corpo da imagem, passando a figurar como elemento constitutivo dessa imagem de dupla-face, as ta'anga.

Retrospectivamente, os espaços habitados por seres não espontaneamente visuais não delimitariam circuitos "fora" do mundo visível, ou "fora" da realidade filmada; tampouco articulariam uma acepção de "dentro" e "fora" da imagem; justamente por realidade e mundos cosmológicos serem indiscerníveis, indissociáveis e possuidores de duplicidade ontológica e bifacialidade corpórea, conjecturando, assim, domínios de experiências ambivalentes e simultâneos, acessados visualmente e não-visualmente, imageticamente e não-imageticamente (DELEUZE, 1985; 1990).

\section{As imagens também são vestidas}

Como dito anteriormente, durante a investigação etnográfica no Mato Grosso do Sul, perseguimos uma formulação conceitual da noção de imagem, sustentada pela cosmologia Kaiowá; e algumas sistematizações em torno das características corpóreas nãohumanas de dupla-face das ta'anga foram possíveis.

Observamos que as imagens só são "imagens" em função de estarem atualizadas sob uma determinada forma estética ocidental denominada por nós de imagem e, na contramão, ao se apresentarem em forma-imagem, as ta'anga "preservariam" sua formacorpo molecular (termo que empregamos aqui em sua acepção deleuzeguattariniana), inalterada em regimes ontológicos de não-visualidade. 
Seres como os angüere (espíritos maléficos), os angüe (reflexos/espíritos benéficos) e os jara (donos-guardiões), por exemplo, podem vir a transformar-se em imagem; e as imagens, por sua vez, podem vir a transformar-se em espíritos, imagensonças, reflexos-porcos, e assim por diante, a depender dos jogos de perspectivas nos quais tais "imagens" estejam associadas.

Algumas parametrizações da teoria etnográfica do perspectivismo ameríndio, elaborada por Eduardo Viveiros de Castro (1996; 2004; 2006; 2018) e Tânia Stolze Lima (1996; 2002), nos fornecem diretrizes teóricas que auxiliam na investigação de pontos relacionados a essa duplicidade ontológica das ta'anga, fundamentalmente no que diz respeito à mútua imbricação entre domínios humanos e não-humanos, "reais" e cosmológicos, visíveis e invisíveis; na experiência empírica e intelectual de nossos interlocutores cineastas Kaiowá.

Um desses parâmetros incide sobre a acepção da operacionalidade de ontologias de dupla-face (visível e não-visível), concernentes a determinados seres e categorias nãohumanos, agentes no multiverso ameríndio:

[...] os animais e outros não-humanos dotados de alma "se veem como" pessoas, e portanto, em condições ou contextos determinados, "são" pessoas, isto é, são entidades complexas, com uma estrutura ontológica de dupla face (uma visível e outra invisível), existindo sob os modos pronominais do reflexivo e do recíproco e os modos relacionais do intencional e do coletivo [...] (VIVEIROS DE CASTRO, 2018, p. 43).

Nossa sugestão é, portanto, a de que as imagens figuram na cosmologia Kaiowá como uma das formas de envelopamento corpóreo possível e passível de ser vestida por variadas categorias de alteridade não-humanas. Os angüere, quando vistos por um xamã, estão envelopados de imagem; uma onça quando vista em um filme está envelopada de imagem, apesar de angüere e onça preservarem sua forma-corpo molecular inalterada em seus domínios ontológicos de origem. Nesse sentido, as imagens vistas sob os regimes de conhecimento de nossos interlocutores são, antes de mais nada, vestes atualizáveis e compatíveis com diferentes corpos.

Trocando em miúdos, as ta'anga não são imagens convencionais devido a uma característica substancializada por essência, inerência, nem tampouco por imanência; ser ou não ser imagem, no pensamento Kaiowá, configura um duplo virtual de múltiplos corpos que podem ser imagetizados ou não, independentemente de quais técnicas e procedimentos de imagetização sejam utilizados para convertê-los em forma-imagem. 
$\mathrm{O}$ ato de acionamento do rec em uma câmera de vídeo, na perspectiva Kaiowá, conquanto, não congela fragmentos de realidades experienciadas exclusivamente pelos humanos, e nem mesmo o agrupamento de imagens em um processo de montagem cinematográfica desenvolve um discurso mimético, codificável e inteligível apenas via linguagem humana; as ta'anga e sua relacionalidade cosmopolítica afetam realidades e sistemas de comunicabilidade mais-que-humanos e, ao mesmo tempo, são igualmente afetadas e inteligidas por eles.

Peter Gow (1995), ao longo de sua etnografia entre os povos amazônicos no Peru, também encontrou ressonâncias similares entre as imagens cinematográficas e as visões xamânicas provocadas pela utilização do ayahuasca. Entre esses coletivos moradores da Amazônia peruana, as imagens evocadas após a ingestão da substância em procedimentos rituais eram chamadas "cinema da floresta" e identificavam, segundo o autor, que a capacidade de produzir/construir imagens, explicitamente, não se caracterizava uma exclusividade operativa dos humanos, tampouco dos equipamentos industrializados de captação e registro cinematográfico.

De acordo com a acepção de Gow (1995), a similaridade das imagens projetadas em uma sala de cinema e as visões produzidas pelo ayahuasca reside no fato de essas duas "categorias" de imagem possuírem uma espécie de origem, ou melhor, de gênese marcadamente posicionada na exterioridade do sujeito, o que permitia aos "nativos" correlacionarem as imagens fílmicas e "ayahuasqueiras" como originadas autonomamente e, consequentemente, oriundas de uma ontologia alternativa à "ontologia dos humanos".

Vejamos:

Tanto ao se assistir a um filme, como na alucinação do ayahuasca, as imagens vistas são percebidas como exteriores ao sujeito no sentido de terem uma origem autônoma. Como num filme, as imagens provocadas pelo ayahuasca não são devaneios nem fantasias, pois não podem ser criadas espontaneamente, nem desaparecem pela vontade do sujeito. (GOW, 1995, p. 45)

Mas isso não é tudo. Haveria, ainda de acordo com a etnografia de Gow (1995), uma especificidade agentiva dos xamãs sobre as imagens "ayahuasqueiras", mobilizada pela utilização de cantos rituais que faziam desses sujeitos operadores extremamente eficazes dessas imagens. Por outro lado, nem mesmo xamãs, nem a própria substância ayahuasca em si, teriam a capacidade de fazer imagens; ambos agentes (xamã e ayahuasca) poderiam apenas administrar fluxos e "afetar processos de transformação, mas não produzir 
alucinações", pois as imagens seriam "geradas e transformadas de acordo com a vontade da ayahuascamama, espirito-mãe da ayahuasca" (GOW, 1995, p. 45).

Em resumo, a categoria imagem, como intentamos conceituar, se trata, quando posta em relação aos regimes de xamanismo, de uma categoria de alteridade mais-quehumana autodeterminada ontologicamente, exatamente por possuir uma gênese corpórea e “espiritual” em domínios ontológicos alternativos ao domínio humano. No nosso caso específico entre os Kaiowá, as ta'anga, de maneira análoga, também são provenientes de uma realidade simultânea, porém alternativa à realidade dos humanos, que faz dessas "imagens" meio e produto de relacionalidades xamânicas complexas, e interpenetradas por agências de seres e sujeitos extrahumanos.

Retrospectivamente, pelo fato de os cineastas Kaiowá inúmeras vezes salientarem que essas múltiplas interferências entre realidades humanas e não-humanas, operadas pelas imagens, determinam restrições e tratamentos direcionados pelos regimes de xamanismo, já que espíritos e donos-guardiões também podem vir a ser imagem; é que podemos, a nosso ver, conferir uma autonomia agentiva das ta'anga, que pode ser comprovada por sua atividade transformacional progressiva.

Lembremos que, de acordo com nossos interlocutores, alguns procedimentos de xamanismo não poderiam ser filmados, em função de a câmera aprisionar as potências não-visuais agentes nesses procedimentos, desestabilizando as relações entre humanos e não-humanos; devido a esse encarceramento de potências, "sugar a força" dos espíritos, e dificultar a eficácia xamânica, fazendo dos velórios e processos de cura, eventos sob restrições de filmagem.

Pois bem, dito isso, avancemos na averiguação das relações entre xamanismo e imagens na cosmologia Kaiowá, para visualizarmos agenciamentos mútuos ainda mais complexos. Segundo Eliel Benites ${ }^{4}$, os xamãs poderiam acessar uma realidade translúcida, transparente e "acima do nosso chão" quando estavam em transe e, para acessar essa realidade, eles deveriam promover uma transformação corporal em si mesmos, que os deixariam igualmente translúcidos, vestidos de um envelope corpóreo compatível à ontologia dessa realidade e que seria uma espécie de imagem.

Nessa realidade estariam muitos dos seres cosmológicos como os ka'i-jaguá (macaco-com-cabeça-de-cachorro), os tejú-jaguá (lagarto-com-cabeça-de-cachorro), os angüe (espíritos), entre outros; e os xamãs somente poderiam acessá-los visualmente, se

\footnotetext{
${ }^{4}$ Como dito anteriormente, Eliel Benites é cineasta Kaiowá e foi interlocutor determinante para a pesquisa etnográfica, realizada de 2017 a 2019.

Rev. Eletrônica Mestr. Educ. Ambient. Rio Grande, Dossiê temático "Imagens: resistências e criações cotidianas", p. 08-27, jun. 2020. E-ISSN 1517-1256
} 
estivessem sob tal envelopamento translúcido. Dito de outra forma, vestir-se de imagem é indispensável para que as imagens exemplifiquem sua atuação, no mundo humano, como forma-imagem que transforma o modo como a vida é vivida.

Logo, os seres oriundos dessa realidade transparente só poderiam ser vistos pelos xamãs, e os xamãs vistos por eles, caso os primeiros estivessem aptos a vestir-se de imagem. Uma imagem que não seria mera imagem, exatamente por possuir afecções e capacidades corpóreas - constituindo, assim, uma espécie de imagem-corpo. Notemos que, assim como a câmera de vídeo dispara ações de transformações corporais nos espíritos, aprisionando-os e transformando-os em imagem, também os xamãs manejam procedimentos de transcorporalidade, que os garantem trânsito em realidades alternativas e simultâneas às dos humanos, via envelopamento imagético. Graças à condição xamânica de transespecificidade corporal, xamãs e imagens atualizam-se mutuamente, a depender dos circuitos ontológicos nos quais necessitam transitar.

É digno de lembrança, recuperando a discussão promovida por Losonczy (1990, p.77) acerca do sistema xamânico Embera (Amazônia Colombiana), que a captura e a fixação momentânea de espíritos e de almas possui uma natureza móvel, de modo que o xamanismo figuraria entre os Embera como o instaurador de uma topografia simbólica que decupa, a partir do território cotidiano e do movimento da sobrenatureza, sobre o corpo humano (seja o do xamã ou dos Embera enfermos). Sendo assim, a ação xamâmica e a topografia simbólica constituída a partir dela comporiam uma estrutura de espaços-signo diferentemente marcados na qual a metamorfose da ação xamânica determinaria, no território e no corpo da pessoa humana, os limites e aberturas que permitem o estabelecimento de relações com diferentes formas de alteridade.

Em tal contexto que a ação xamânica se configura como um modo de contato entre formas ontologicamente distintas e de inscrição de uma topografia sociocósmica em diferentes formas corporais, se poderia dizer, para o caso dos Kaiowá, que a comunicabilidade entre xamãs e seres da "realidade transparente" só pode ser operacionalizada mediante transformações corpóreas que envelopem os corpos dos xamãs nessa forma-corpo-imagem também transparente; fazendo com que a circunscrição corpórea das imagens, na cosmologia Kaiowá, possa ser aferida. Ou seja, imagens e xamanismo, para os regimes de conhecimento de nossos interlocutores, protagonizam mosaicos relacionais extremamente sofisticados, os quais produzem, correlativamente, efeitos de atualização ontológica em ambos os corpos: das imagens e dos xamãs.

Rev. Eletrônica Mestr. Educ. Ambient. Rio Grande, Dossiê temático "Imagens: resistências e criações cotidianas", p. 08-27, jun. 2020. E-ISSN 1517-1256 
As ontologias de dupla-face, evocadas nas características bifaciais dessas duas categorias de sujeitos (imagem e xamã), (re)orientam o entendimento do que viria a ser as ta'anga, distanciando a noção de imagem Kaiowá de prescrições semióticas e discursivas, pois as imagens, antes de representarem signos articuladores de discurso, são representantes de uma discursividade mais-que-humana, inextricável de seu próprio corpo. Xamãs podem vir a ser imagem, ou melhor, podem vir a se vestir de imagem, para acessar domínios de experiência não-humanos; assim como imagens podem vir a vestir-se de xamãs, de onças e de porcos nas telas de projeção de filmes, televisores e smartphones, por exemplo.

\section{A câmera é corpo}

Nesta seção desenvolveremos alguns argumentos em torno de uma espécie de (re)posicionamento ontológico do dispositivo-câmera nos regimes cosmológicos Kaiowá. Nossa argumentação alinhavará pessupostos oriundos da sistematização de dados etnográficos, elaborados em pesquisas de campo realizadas ao longo dos anos de 2017 e 2019, em diferentes territórios Kaiowá do Cone Sul de Mato Grosso do Sul.

Pareceu-nos, naquele período, que a câmera, enquanto aparato técnico, tecnológico e mecânico, vista com os olhos de nossos interlocutores, configurava-se como um corpo autodeterminado ontologicamente, exatamente por ostentar uma "natureza" maquínica e, por conseguinte, não-humana; aspecto, que desejamos agora, prolongar e complexificar teoricamente.

Uma câmera que é capaz de filmar o não-visível, também será capaz de agir em esferas de não-visualidade e, na contramão, ser vista e afetada por elas. Tal constructo relacional deflagra uma espécie de inversão produzida pela ontologia Kaiowá a respeito de uma "condição" sociocosmológica da câmera, de certo modo distanciada de seus contextos de produção industriais não-indígenas, como se tal dispositivo adquirisse considerável autonomia de sua gênese fabril, para, progressivamente, corporificar em si mesmo; uma contra-gênese referencialmente alocada nos domínios da cosmologia.

Não queremos dizer com isso que os cineastas Kaiowá neguem ou desconheçam que os espaços físicos e simbólicos de fabricação das câmeras sejam as filiais da Canon na China, ou as sucursais da Nikon em Hong Kong; na verdade, desejamos pôr em relevo o avesso disso, ou seja, o quanto o conhecimento euro-centrado desconhece e negligencia capacidades extra-mundanas dos objetos que ele próprio fabrica. 
De um ponto de vista "histórico", pode-se afirmar que os países ditos desenvolvidos e/ou industrializados produziram as máquinas de registro de imagens e apresentaram-nas aos índios, mas, por outro lado, nosso objetivo e esforços, aqui empenhados, são movidos no sentido contrário: tal conceituação cosmológica da câmera operada pelo pensamento Kaiowá poderá nos fornecer uma imagem menos distorcida do que vem a ser uma câmera, e quais são suas potencialidades e eventuais periculosidades para vidas humanas e nãohumanas, exatamente por essa conceituação posicionar-se temporalmente no avesso de uma "história histórica".

A câmera, por se tratar de um corpo-dispositivo capaz de desestabilizar o arranjamento do mundo dos espíritos e dos humanos, por exemplo, abre caminhos para vislumbrarmos sua contra-gênese no tempo pré-cosmológico. Por óbvio, necessitaremos de mais tempo e campo para esmiuçar a proposta Kaiowá de gênese da câmera, mas, por hora, nos satisfazemos em identificar a incompatibilidade entre os tratamentos históricos e cosmológicos, para refletirmos as agências do dispositivo-câmera nas agendas ameríndias.

Enquanto na corrente humanista fala-se de uma câmera-corpo - de uma câmera que simboliza e representa o agir e ver do corpo humano que a maneja, como se o olhar produzido pela câmera fosse um equivalente ao ponto de vista/olhar do pesquisador/autor sob o regime perspectivista, a câmera configura-se inversamente: como um corpo-câmera. Menos que uma extensão do corpo de quem a utiliza para filmar, como prescreve a teoria da câmera humanizada (MACDOUGALL, 2009), a própria câmera, ela mesma, do ponto de vista ameríndio, também se configura como um corpo autônomo.

Se os espíritos são seres a princípio não-visíveis, mas que emanam energias potenciais a partir de seus corpos, e tais energias, apesar de não-visíveis, são passíveis de serem absorvidas pela câmera; esta câmera passa, com isso, a possuir uma atribuição "corpórea" até então inexistente no universo ontológico não-indígena: ela não registra apenas os enquadramentos de mundos visualizáveis diante de sua objetiva, mas, antes, ela é capaz de aprisionar corpos e seres não-visuais presentes nestes mundos.

Tânia Stolze Lima (2002), ao investigar a noção de corpo entre os Juruna, conclui que a invisibilidade de um corpo e, portanto, de um ser não está vinculada a uma essência corpórea impossível de ser visualizada; pois o status de invisível será sempre relacional a uma "capacidade visual do observador". Em nosso caso, esse "corpo-câmera Kaiowá" ostentaria exatamente uma "capacidade de observador" que a câmera "comum", ou melhor, que "câmera-não-indígena” não possui. 
Quando dizemos que a "câmera-não-indígena" detém tal incapacidade observacional, não é porque os equipamentos (câmera-indígena e câmera-não-indígena) são distintos entre si do ponto de vista maquínico e/ou fabril; mas, sim, porque a diferença entre eles consiste em suas gêneses ontológicas, das quais originam-se capacidades relacionais e operativas específicas para cada "modalidade" de câmera, em função de elas mobilizarem ontologias díspares, "condensadas" em suas materialidades corpóreas.

Existe aí um jogo duplo: de um lado, a "câmera-indígena", que é capaz de absorver o invisível e inscrevê-lo em suporte; e de outro, a "câmera-não-indígena", que apenas maneja o invisível por espaços e/ou instâncias que estariam fora da imagem, em domínios do extra-campo e/ou do "fora de quadro".

Nesse sentido, a "câmera-corpo" humanista não seria capaz de ver e filmar os espíritos, dado o fato de que ela é um "observador" incapaz de se colocar em um campo visual no qual transitam e vivem os espíritos; mas por outro lado, o mesmo não pode ser aferido acerca do "corpo-câmera" ameríndio, que, por sua vez, é capaz, não apenas de se colocar no campo visual no qual transitam e vivem os espíritos, como também é capaz de filmá-los e inscrevê-los em suporte fílmico.

No desenvolvimento teórico perspectivista que Tânia Stolze Lima (2002) nos fornece acerca do que podem os corpos nas cosmologias ameríndias, esse duplo ver/servisto, em campos visuais ontologicamente alternativos, depende da capacidade específica com a qual cada corpo relaciona-se em domínios "visíveis" e "invisíveis" simultâneos:

[...] A visibilidade ou invisibilidade de um corpo não dependem de uma característica própria a ele mas de uma capacidade visual do observador. Se não vejo um espírito é por incapacidade de meus olhos. Se um espírito me vê, só vê aquilo que de mim eu própria não posso ver: minha alma, a qual representa todo o meu corpo para ele, toda a minha pessoa. Além disso, um observador capacitado para ver espíritos, como o xamã, vê o que os espíritos vêem, situa-se, portanto, no seu campo visual. Ou seja, não se pode vê-los sem ao mesmo tempo fazer-se visível para eles [...] (LIMA, 2002, p. 4).

Pois bem, o modo como se vê através de uma câmera não é o mesmo modo como se vê sem ela, ao passo que o que se vê através de uma câmera só pode ser visto do modo como é visto através dela. Ou seja, as capacidades e as características observacionais específicas da câmera são dependentes e inextricáveis das especificidades concernentes ao seu corpo de câmera.

Rev. Eletrônica Mestr. Educ. Ambient. Rio Grande, Dossiê temático "Imagens: resistências e criações cotidianas", p. 08-27, jun. 2020. E-ISSN 1517-1256 
Em outras palavras, a lente não é um olho e nem de longe é o equivalente do olho; no máximo sua capacidade de ver é análoga à capacidade do olho, mas os modos como cada um vê não se equivalem, tampouco se anulam, na verdade, se potencializam.

Christian Suhr e Rane Willerslev (2012) apresentam questões relevantes acerca da incompatibilidade entre as ontologias da teoria da câmera humanizada e os contextos indígenas, fundamentando sua crítica a partir da noção de que o estatuto corpóreo da câmera não reside em uma instância equivalente ao corpo humano, e, sim, em uma instância mecânica, e, porquanto, não-humana:

[...] a camera is not a human eye but a mechanical eye, which, rather than a continuous stream of vision, provides a series of frames with a limited range of contrast, color reproduction, depth of field, and angle. The real wonder of cinema, we venture to suggest, lies not in its inferior imitation of the human eye, but rather in its mechanical capturing of footage, which subsequently can be put together with other pieces by way of montage. Our task here is to explore how ethnographic filmmaking may expand our horizon of experience, if we take seriously the key differences between the camera eye and the human eye and consider the use of manipulative filmic devices for transcending the limitations of human vision. [...] it is only when we embrace its mechanical, nonhuman nature that the medium of film can become fully capable of conveying the invisible [...] (SUHR, WILLERSLEV, 2012, p. 283).

De acordo com Suhr e Willerslev, seria exatamente esta conceituação não-humana da câmera nos regimes intelectuais indígenas que distanciaria a aplicabilidade da noção de câmera humanizada nesses contextos. Segundo os autores, a "natureza não-humana" da câmera é o que a faz capaz de "transportar o invisível" nos filmes e, com isso, a ideia humanista-cartesiana de que é impossível filmar o invisível, não se aplica às capacidades deste corpo-câmera.

Voltando por um instante à intervenção de André Brasil e Bernard Belisário (2016), podemos identificar a utilização do termo corpo-câmera, mas sob um tratamento conceitual diferente do que desejamos propor. Para os autores, a expressão enseja a formulação textual de um arranjo relacional, ou melhor, a sintetização em forma-texto da relação corpo humano e câmera. Vejamos que corpo continua sendo o corpo do humano por trás da câmera, e a câmera continua sendo a máquina que, manejada pelo corpo humano, permite a produção de imagens.

Notemos:

Mais do que uma assimilação de códigos prévios, filmar (assim como o aprendizado técnico de manejo da câmera) envolve um saber 
corporal, em mútua reconfiguração entre corpo e máquina [...] os filmes guardam em comum o fato de que, acoplado à câmera, o corpo do cineasta não se furta nem se protege do atrito com o mundo. Trata-se de um corpo que, ao filmar, marca sua presença em cena, deixando-se, por sua vez, afetar por aquilo que filma. A imagem é o índice de uma relação mediada pela câmara. (BRASIL; BELISÁRIO, 2016, p. 604)

Pois bem, o trecho acima nos permite a visualização da noção de corpo-câmera dos autores, a qual incide sobre o acoplamento entre "o corpo do cineasta" e a câmera; e que aqui desejamos problematizar, de modo que o leitor e a leitora possam perseguir, com mais destreza, a diferença de nossa formulação a respeito da acepção conceitual de corpocâmera.

De um lado, antes de nos referirmos a uma espécie de junção entre o corpo de um humano e o equipamento-câmera para que se produza imagens, nosso entendimento da expressão está referenciado a um estatuto corporal autônomo, ostentado pela câmera no pensamento Kaiowá. De outro, menos que "o índice de uma relação mediada pela câmera", as imagens configuram-se corpos transmorfos produzidos pela ação da câmera.

Ora, se a câmera é um agente capaz de aprisionar potências não-visuais das coisas e dos seres de mundos ontologicamente distintos (espíritos, onças, árvores e humanos), e transcorporificá-los em forma-imagem, esse "equipamento" assume capacidades pragmáticas e cosmopolíticas; deixando de ser mero instrumento e/ou acoplamento entre humano e máquina, para figurar ele próprio a categoria de sujeito, e, por ser sujeito, ele possui, antes de mais nada, um corpo.

Em resumo, a câmera não precisa de um corpo humano a manejando para ser dotada de corpo e, por isso, corpo-câmera diz respeito, acima de tudo, a uma autodeterminação ontológica da câmera, olhada através das lentes cosmológicas de nossos interlocutores. Lembremos que, sob o perspectivismo ameríndio, o status de sujeito depende inextricavelmente de autonomia corpórea, o que, consequentemente, garante, também, autonomia de perspectiva.

Ou seja, se a câmera é um corpo capaz de agir sobre outros corpos, é porque possui circunscrição corpórea, e atua em jogos de perspectiva. Enfim, entendemos a câmera como um corpo-câmera, porque o paradigma primordial Kaiowá, no tocante à "natureza" da câmera, não está no problema de ser câmera, e sim no problema de ser corpo; antes de uma continuidade e/ou acoplamento entre humano e câmera, a câmera, ela mesma, configura-se como um corpo-outro, possuidor de agência, perspectiva e intencionalidades circunscritas às capacidades e às limitações de seu corpo autônomo.

Rev. Eletrônica Mestr. Educ. Ambient. Rio Grande, Dossiê temático "Imagens: resistências e criações cotidianas", p. 08-27, jun. 2020. E-ISSN 1517-1256 


\section{Alguma conclusão}

Por hora, é possível dizer que os filmes Kaiowá capilarizam inferências políticas de intensidades inimagináveis para contextos referenciais mononaturalistas, em função de as produções circularem em domínios de atuação cosmopolítica, propulsionadores de permeabilidades fruitivas que permitem às imagens não estarem estagnadas e restritas a circuitos de comunicabilidade humanos.

À vista disso, essa espécie de avessamento filosófico do que vem a ser uma imagem e do que pode uma câmera, por exemplo, demonstra que a contribuição oferecida pelo pensamento Kaiowá afeta política e fenomenologicamente os campos da etnologia e do cinema, possibilitando o alargamento dos estudos da imagem via cosmologia.

Nesse sentido, para efeitos conclusivos, três aspectos fundamentais podem ser sistematizados a partir desse esgarçamento: 1) o debate acerca das potencialidades políticas do cinema indígena, de uma maneira geral, estarão esvaziados, caso não sejam consideradas as capacidades agentivas mais-que-humanas das imagens e dos aparatos tecnológicos com os quais se faz filmes; 2) os filmes indígenas devem ser entendidos como dispositivos relacionais multivetoriais, que interferem e agem em realidades humanas e não-humanas simultâneas, interpenetráveis entre si, e que potencializam o caráter político das imagens em linhas rizomáticas as quais afetam, não apenas espectadores, críticos, curadores, cineastas, festivais, canais de TV, universidades e etc, mas também espíritos, animais, pedras, sereias, cobras-com-cabeça-de-cachorro, tamanduás-comedores-de-gente e assim sucessivamente; e 3) os regimes de conhecimento Kaiowá reivindicam que a capacidade do pensamento ameríndio de manejar a "linguagem audiovisual" não foi inaugurada por técnicas e procedimentos apropriados dos brancos, já que a comunicabilidade relacional através de imagens, há muito, é dominada por xamãs, espíritos e demais não-humanos que comunicam-se entre si desde períodos predecessores ao contato entre brancos e índios, por meio das possibilidades de envelopamento imagético.

Em resumo, as ta'anga multiplicam as possibilidades políticas dos filmes, ao passo que participam de uma espécie de criação de novos circuitos passíveis de atuação dos filmes. De universidades aos festivais de cinema, de exibições para parentes em reservas e em aldeias aos mundos cosmológicos onde transitam xamãs, cobras-com-cabeça-decachorro e tamanduás gigantes; as imagens Kaiowá esgarçam a própria noção de ação política da qual são capazes as imagens e os dispositivos-câmera.

Rev. Eletrônica Mestr. Educ. Ambient. Rio Grande, Dossiê temático "Imagens: resistências e criações cotidianas", p. 08-27, jun. 2020. E-ISSN 1517-1256 


\section{Referências}

BRASIL, André; BELISÁRIO Bernard. Desmanchar o cinema: variações do fora-decampo em filmes indígenas. Revista Sociologia e Antropologia. Rio de Janeiro, UFRJ v.6, 2016.

DEBAISE, Didier; STENGERS, Isabelle. L'insistance des possibles: pour un pragmatisme spéculatif. In: Multitudes, n. 65, (4), p. 82-89, 2016.

DELEUZE, Gilles; GUATTARI, Félix. Mil Platôs. Capitalismo e Esquizofrenia. Rio de Janeiro: Editora 34, 1995.

DELEUZE, Gilles. A Imagem-Tempo. São Paulo: Brasiliense, 1990.

DELEUZE, Gilles. A Imagem-Movimento. São Paulo: Brasiliense, 1985.

GOW, Peter. Cinema da floresta: Filme, alucinação e sonho na Amazônia peruana. Revista de Antropologia, v.38, n.2, USP. São Paulo, 1995.

LATOUR, Bruno. Quel cosmos? Quelles cosmopolitics? In: LOLIVE, J.; SOUBEYRAN, O. (Org.). L’emergence des cosmopolitiques. Paris: La Découverte, 2007.

LIMA, Tânia Stolze. O Dois e seu Múltiplo: Reflexões sobre o Perspectivismo em uma Cosmologia Tupi. Revista Mana, (2): 21-47, PPGAS, Museu Nacional, UFRJ. Rio de Janeiro, 1996.

LIMA, Tânia Stolze. O que é um corpo? Revista Religião e Sociedade, 22 (1): 9-20, Rio de Janeiro, 2002.

MACDOUGALL, David. Significado e ser. In: BARBOSA, Andrea; CUNHA, Edgar Theodoro da.; HIKIJI, Rose Satiko Gitirana (Org.). Imagem-conhecimento:

Antropologia, cinema e outros diálogos. Campinas: Papirus, 2009.

LOSONCZY, Anne-Marie. La Maîtrise du multiple. Corps et espace dans le chamanisme embera du Choco (Colombie). L'Homme. tome 30 n.114. p. 75-100, 1990.

STENGERS, Isabelle. A proposição cosmopolítica. Revista do Instituto de Estudos Brasileiros, n. 69, 2018.

STENGERS, Isabelle. Comparison as a Matter of Concern. Common Knowledge, vol. 17 no. 1,2011

SUHR, Christian; WILLERSLEY, Rane. Can Film Show the Invisible? The Work of Montage in Ethnographic Filmmaking. Chicago Journals, vol. 53, University of Chicago, 2012.

VIVEIROS DE CASTRO. Metafísicas Canibais. Editora UBU, São Paulo, 2018. 
VIVEIROS DE CASTRO. 'Transformação' na Antropologia, transformação da 'Antropologia'. Revista Mana, n. 18, UFRJ, Rio de Janeiro, 2012.

VIVEIROS DE CASTRO. A floresta de cristal. Revista Cadernos de Campo, USP, São

Paulo, 2006.

VIVEIROS DE CASTRO. Exchanging perspectives - The Transformation of Objects into Subjects in Amerindian Ontologies, Symposium: Talking Peace with Gods, Part 1 , Durham, 2004.

VIVEIROS DE CASTRO. Os pronomes cosmológicos e o perspectivismo ameríndio. Revista Mana, UFRJ, Museu Nacional, Rio de Janeiro, 1996.

Submetido em: 17-03-2020.

Publicado em: 01-07-2020. 